\title{
KEDUDUKAN UNDANG-UNDANG KEORMASAN TERHADAP KEHIDUPAN BERDEMOKRASI DI INDONESIA
}

\section{Andhi Setya Budi, Subarkah dan Suparnyo}

Email : andhisetyabudi@yahoo.co.id, subarkah_sh@yahoo.com, suparnyo@umk.ac.id Fakultas Hukum Universitas Muria Kudus

\begin{abstract}
ABSTRAK
Undang-Undang Dasar Negara Republik Indonesia mengatur bahwa Presiden berhak menetapkan Peraturan Pemerintah Pengganti Undang-Undang (Perppu). Penetapan Perppu oleh Presiden hanya boleh dilakukan ketika dalam kondisi ihkwal kegentingan yang memaksa. Pada tahun 2017, Presiden Joko Widodo menetapkan Perppu Nomor 2 Tahun 2017 tentang Perubahan Atas Undang-Undang Nomor 17 Tahun 2013 tentang Organisasi Kemasyarakatan. Pada sidang paripurna DPR, DPR menyetujui Perppu tersebut dan mengesahkan menjadi Undang-Undang Nomor 16 Tahun 2017. Akibatnya, terjadi kegaduhan di masyarakat yang sebagian menganggap bahwa Perppu tersebut menciderai nilai-nilai demokrasi di Indonesia. Permasalahan yang akan dibahas adalah: 1. Bagaimana kedudukan undang-undang keormasan terhadap kehidupan berdemokrasi di Indonesia? 2. Bagaimana dimensi kegentingan memaksa dalam penetapan Perppu Nomor 2 Tahun 2017 tentang Organisasi Kemasyarakatan? Metode pendekatan pada penelitian ini adalah pendekatan yuridis normatif, spesifikasi penelitian ini adalah deskriptif analitis, jenis data yang digunakan adalah data sekunder, dengan cara studi pustaka dan studi dokumenter, metode analisisnya menggunakan metode kualitatif. Pada undang-undang keormasan sebelum Perppu Nomor 2 Tahun 2017 ditetapkan, mekanisme pembubaran ormas melalui putusan pengadilan. Namun, setelah ditetapkannya Perppu tersebut, Kementerian terkait dapat mencabut status badan hukum dari ormas, yang sama saja membubarkannya. Hal ini berdasarkan asas contrario actus. Hal ikhwal kegentingan yang memaksa yang melatarbelakangi ditetapkannya Perppu tersebut karena UU No. 17 Tahun 2013 tentang Ormas sudah tidak mampu memenuhi kebutuhan hukum saat ini. Khususnya yang berkaitan dengan ormas yang mengancam ideologi Pancasila yang harus segera ditindaklanjuti. Namun batasan tentang ancaman terhadap ideologi Pancasila perlu diperjelas agar tidak menjadi polemik dalam Pemerintah mengambil tindakan kepada ormas yang dianggap mengancam ideologi Pancasila.
\end{abstract}

Kata Kunci : Perppu/UU Ormas, Organisasi Kemasyarakatan, Demokrasi 


\section{PENDAHULUAN}

Salah satu wujud pelaksanaan ketentuan dalam Pasal 28 UUD NRI 1945 yaitu Pemerintah Indonesia mengundangkan Undang-Undang Nomor 17 Tahun 2013 tentang Organisasi Kemasyarakatan dan Undang-Undang Nomor 9 Tahun 1998 tentang Kemerdekaan Menyampaikan Pendapat di Muka Umum. Kedua undang-undang tersebut telah mencantumkan hak-hak setiap warga negara sebagai bentuk perlindungan pemerintah terhadap hak asasi manusia (HAM).

Dalam keadaan yang normal, sistem norma hukum diberlakukan berdasarkan undang-undang dasar dan perangkat peraturan perundangundangan yang secara resmi diadakan untuk mengatur berbagai aspek yang berkenaan dengan penyelenggaraan kegiatan bernegara pada umumnya. ${ }^{41}$ Tetapi terkadang, kurang terbayangkan bahwa akan ada keadaan lain yang bersifat tidak normal, dimana sistem hukum yang biasa itu tidak dapat diharapkan efektif untuk mewujudkan tujuan hukum itu sendiri.

Salah satu diantara berbagai persoalan kehidupan berbangsa dan bernegara pada tahun 2017 adalah saat Presiden Joko Widodo membuat Peraturan Pemerintah Pengganti Undang-Undang (Perppu) tentang perubahan atas Undang-Undang Organisasi Kemasyarakatan (10/7/2017). Adapun argumen terkait diterbitkannya Perppu, intisarinya sebagai berikut: ${ }^{42}$

${ }^{41}$ Maria Farida Indrati S, "Ilmu PerundangUndangan: Jenis Fungsi dan Materi Muatan", Kanisius, Yogyakarta, 2007, hlm 215.

42 Sudjito, 'Membaca 'Kepentingan Politik' Dibalik Perppu Ormas dan Implikasi a. Perppu tersebut diterbitkan dalam rangka tugas pemerintah untuk melindungi segenap bangsa dan tumpah darah Indonesia.

b. Organisasi kemasyarakatan (Ormas) di Indonesia yang saat ini mencapai 344.039 ormas, telah beraktifitas di segala bidang kehidupan, baik dalam tingkat nasional maupun di tingkat daerah, harus diberdayakan dan dibina, agar dapat memberikan kontribusi positif bagi pembangunan nasional.

c. Kenyataannya saat ini, terdapat kegiatan-kegiatan organisasi kemasyarakatan (ormas) yang bertentangan dengan Pancasila dan Undang-Undang Dasar Negara Republik Indonesia 1945. Ini merupakan ancaman terhadap eksistensi bangsa, dengan telah menimbulkan konflik di masyarakat.

d. Undang-Undang Nomor 17 Tahun 2013 tentang Organisasi Kemasyarakatan tidak lagi memadai sebagai sarana untuk mencegah meluasnya ideologi yang bertentangan dengan Pancasila dan UUD NRI 1945, baik dari aspek substantif terkait dengan norma, larangan, dan sanksi serta prosedur hukum yang ada. Antara lain, tidak terwadahinya azas hukum administrasi contrario actus yaitu azas hukum bahwa lembaga yang mengeluarkan

Sosiologisnya Terhadap Masyarakat", (Makalah disampaikan dalam Seminar Nasional Quo Vadis Perppu Ormas pada Tanggal 19 Oktober 2017 di UII Yogyakarta), hlm. 1. 
izin atau yang memberikan pengesahan adalah lembaga yang seharusnya mempunyai wewenang untuk mencabut atau membatalkannya.

e. Selama ini, pengertian tentang ajaran dan tindakan yang bertentangan dengan Pancasila dirumuskan secara sempit yaitu hanya sebatas pada ajaran Atheisme, Marxisme, dan Leninisme. Padahal sejarah Indonesia membuktikan bahwa ajaran-ajaran lain juga bisa dan bertentangan dengan Pancasila.

Melengkapi atas pemahaman terbitnya Perppu yang dalam syarat materilnya menyebutkan kegentingan yang memaksa, Mahkamah Konstitusi sebagai penafsir konstitusi ${ }^{43}$ melalui Putusan Nomor 138/PUU-VII/2009, menafsirkan frasa kegentingan yang memaksa dalam Pasal 22 UUD NRI 1945 dengan tiga syarat sebagai berikut: ${ }^{44}$

1. Adanya keadaaan yaitu kebutuhan mendesak untuk menyelesaikan masalah hukum secara cepat berdasarkan undang-undang;

2. Undang-undang yang dibutuhkan tersebut belum ada sehingga terjadi kekosongan hukum, atau ada undang-undang tetapi tidak memadai;

43 Jimly Asshiddiqie, "Perkembangan dan Konsolidasi Lembaga Negara Pasca reformasi", Sekretariat Jenderal dan Kepaniteraan Mahkamah Konstitusi RI, Jakarta, 2006, hlm. 154-155.

44 Pertimbangan Hukum Majelis Hakim dalam Putusan Mahkamah Konstitusi No. 138/PUU-VII/2009 tentang Pengujian Perppu Nomor 4 Tahun 2009 tentang Perubahan Atas Undang-Undang Nomor 30 Tahun 2002 tentang Komisi Pemberantasan Tindak Pidana Korupsi (KPK).
3. Kekosongan hukum tersebut tidak dapat diatasi dengan cara membuat undang-undang secara prosedur biasa karena akan memerlukan waktu yang cukup lama sedangkan keadaan-keadaan yang mendesak tersebut perlu kepastian untuk diselesaikan.

Keadaan di atas menjadi perhatian yang lebih serius dikarenakan DPR sebagai manifestasi dari suara rakyat menerima kehadiran Perppu Nomor 2 Tahun 2017 tersebut. Sebagaimana yang dikutip dari harian Kompas, Mayoritas fraksi di DPR menerima Perppu Nomor 2 Tahun 2017 tentang Perubahan Atas Undang-Undang Nomor 17 Tahun 2013 tentang Organisasi Kemasyarakatan untuk disahkan menjadi undang-undang dalam Rapat Paripurna pada Selasa (24/10/2017). Tujuh fraksi yang menerima, yakni PDI-P, Golkar, PKB, PPP, Nasdem, Hanura dan Demokrat. Namun, tiga fraksi di antaranya, yakni PPP, PKB, dan Demokrat, menerima dengan catatan agar Perppu tersebut segera direvisi setelah diundangkan. ${ }^{45}$

Melihat keadaan politik hukum saat ini, langkah Pemerintah dengan membentuk Perppu Nomor 2 Tahun 2017 tentang Perubahan Atas UndangUndang Nomor 17 Tahun 2013 tentang Organisasi Kemasyarakatan menuai banyak kecaman namun juga tak sedikit yang mendukung langkah Pemerintah, sebagaimana DPR dalam sidang Paripurna, demi tercapainya ketentraman dalam berbangsa dan bernegara.

\footnotetext{
${ }^{45}$ Rakhmat Nur Hakim, "Tujuh Fraksi Menerima Perppu Ormas, Tiga Menolak", http://nasional.kompas.com, 1 Maret 2018
} 


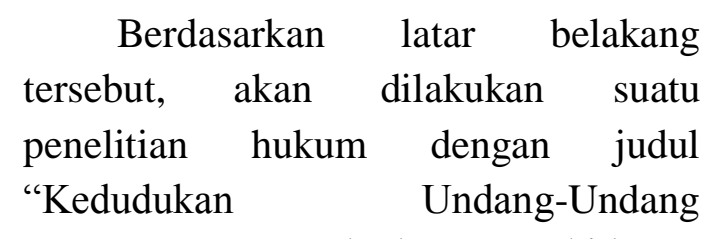

Keormasan Terhadap Kehidupan Berdemokrasi di Indonesia dengan rumusan permasalahan sebagai berikut :

a. Bagaimanakah kedudukan UndangUndang Nomor 16 Tahun 2017 tentang Penetapan Perppu Nomor 2 Tahun 2017 tentang Perubahan Atas Undang-Undang Nomor 17 Tahun 2013 tentang Organisasi Kemasyarakatan dalam kehidupan berdemokrasi di Indonesia?

b. Bagaimana dimensi kegentingan yang memaksa dalam penerbitan Perppu Nomor 2 Tahun 2017 tentang Perubahan Atas UndangUndang Nomor 17 Tahun 2013 tentang Organisasi Kemasyarakatan?

\section{METODE PENELITIAN}

Penelitian ini menggunakan pendekatan yuridis normatif, yaitu penelitian dengan menggunakan data sekunder. Tipologi penelitian ini bersifat preskriptif. Preskriptif berarti memberikan saran, penyelesaian dan usulan terhadap penelitian. Dalam penelitian ini, saran yang akan diberikan adalah mengenai implementasi Perppu disaat kapan, apa dan bagaimana perppu dapat digunakan. Jenis data yang digunakan adalah data sekunder, yaitu data yang diperoleh dari kepustakaan. Alat pengumpulan data adalah melalui penelusuran literatur atau studi dokumen. Metode analisis data dilakukan dengan pendekatan kualitatif, yaitu metode yang menghasilkan data berupa uraian mengenai apa yang dinyatakan oleh sasaran penelitian, dan kebenaran data atau premis akhir penelitian ditentukan oleh penelitinya sendiri. Dengan demikian, bentuk penelitian ini berupa penelitian yang preskriptif analitis.

\section{PEMBAHASAN}

\section{Kedudukan Undang-Undang Organisasi Kemasyarakatan dalam Kehidupan Demokrasi di Indonesia}

Indonesia merupakan negara hukum dan demokratis. Penciri dari negara demokrasi yang berdiri dalam konsepsi hukum adalah adanya masyarakat madani, infrastruktur politik yang meliputi partai politik dan organsiasi masyarakat (ormas), dan juga adanya pers yang bebas serta bertanggung jawab. Salah satu poin penting dalam negara demokrasi adalah adanya jaminan kebebasan berserikat yang terefleksikan dalam pendirian ormas sebagai wadah masyarakat untuk berpendapat, berserikat dan berkumpul. $^{46}$

Sedikitnya ada tiga aspek yang dapat dijadikan landasan untuk mengukur sejauh mana demokrasi berjalan dalam suatu negara atau apakah suatu negara atau pemerintah dapat dikatakan sebagai pemerintah yang demokratis atau sebaliknya. Ketiga aspek tersebut antara lain: ${ }^{47}$

1. Pemilihan Umum sebagai proses pembentukan pemerintah. Pemilihan umum salah satu instrumen penting dalam pergantian pemerintahan.

\footnotetext{
46 Dian Kus Pratiwi, "Implikasi Yuridis Peraturan Pemerintah Pengganti UndangUndang Nomor 2 Tahun 2017 tentang Perubahan atas Undang-Undang Nomor 17 Tahun 2013 tentang Organisasi Kemasyarakatan di Indonesia”, https://doi.org/10.22304/pjh.v4n2.a4, 10 Agustus 2017

${ }^{47}$ Fuady Munir, "Konsep Negara Demokrasi”, Retika Aditama, Jakarta, 2009. hlm. 37
} 
2. Susunan kekuasaan negara, yaitu kekuasaan negara dijalankan secara distributive untuk menghindari penumpukan kekuasan dalam satu tangan.

3. Kontrol rakyat atau adanya mekanisme yang memungkin kontrol dan keseimbangan (check and balance).

Dikeluarkannya Perppu Nomor 2 Tahun 2017 tentang Perubahan atas Undang-Undang Nomor 17 Tahun 2013 tentang Organisasi Kemasyarakatan menunjukkan adanya kekhawatiran pemerintah bahwa paham radikalisme sudah di ambang batas dan bisa mengganggu keutuhan NKRI, sehingga harus segera dilakukan langkah antisipasi agar keutuhan NKRI dan keamanan negara dapat terjaga dari rongrongan paham radikalisme terutama terhadap kelompok atau ormas yang mempermasalahkan Pancasila sebagai dasar Negara dan pandangan hidup bangsa Indonesia.

Sejak Presiden Joko Widodo menerbitkan Perppu Nomor 2 Tahun 2017 tentang Perubahan UndangUndang Nomor 17 Tahun 2013 tentang Organisasi Kemasyarakatan, polemik pun tak terhindarkan. Ini dikarenakan Perppu tersebut tidak mewajibkan pemerintah mengikuti proses pengadilan untuk membubarkan sebuah organisasi kemasyarakatan, hal ini oleh sebagian kalangan dinilai bertentangan dengan Pancasila dan melanggar konstitusi. $^{48}$

Perppu adalah peraturan perundang-undangan yang ditetapkan oleh Presiden dalam hal ihwal kegentingan yang memaksa sebagaimana diatur dalam ketentuan Pasal 22 UUD NRI 1945. Maria Farida

\footnotetext{
${ }^{48}$ Voaindonesia.com, 10 Agustus 2017
}

Indrati Soeprapto menerangkan bahwa Perppu merupakan peraturan pemerintah (PP) yang menggantikan kedudukan undang-undang, maka materi muatannya adalah sama dengan materi muatan dari undang-undang. ${ }^{49}$

Jimly Asshidiqie, berpendapat bahwa syarat materiil untuk penetapan Perppu yaitu:

a. Adanya kebutuhan mendesak untuk bertindak atau reasonable necessity;

b. Waktu yang tersedia terbatas atau terdapat kegentingan waktu; dan

c. Tidak tersedia alternatif lain diperkirakan tidak akan dapat mengatasi keadaan, sehingga penetapan Perppu merupakan satu-satunya cara untuk mengatasi keadaan tersebut.

Perppu Ormas perlu mendapat persetujuan DPR dalam jangka waktu 1 (satu) tahun setelah Perppu tersebut ditetapkan. Pada tanggal 24 Oktober 2017 DPR dalam rapat paripurna yang dipimpin oleh Fadli Zon mengesahkan Perppu Nomor 2 Tahun 2017 menjadi undang-undang melalui pemungutan suara.

Ada tiga hal yang dianggap mendesak oleh pemerintah untuk mengadakan perubahan UndangUndang Nomor 17 Tahun 2013 yaitu:

1. Bahwa UU Ormas 2013 belum mengatur secara jelas dan komprehensif ormas yang dapat dikatakan bertentangan dengan Pancasila dan UUD NRI Tahun 1945.

2. Pemerintah mensinyalir ada beberapa Ormas yang dalam

\footnotetext{
${ }^{49}$ Maria Farida Indrati Soeprapto, "Ilmu Perundang-undangan Dasar-Dasar dan Perkembangannya”, Kanisius, Yogyakarta, 1998, hlm. 131.
} 
melaksanakan aktifitasnya tidak sesuai dengan Anggaran Dasar dan Anggran Rumah Tangga Ormas bersangkutam.

3. UU Ormas 2013 belum mengatur tentang contrarius actus.

Perubahan yang mendasar pada UU Keormasan adalah tentang larangan ormas sebagaimana diatur dalam Pasal 59 serta ketentuan sanksi yang diatur dalam Pasal 60 serta pemberian kewenangan terhadap kementerian terkait (Kemendagri dan Kemenkumham khususnya) guna memberikan sanksi. Serta dihapusnya ketentuan Pasal 63 sampai dengan Pasal 68 pada UU Ormas 2013 dan diganti dengan yang baru. Perubahan norma tersebut menurut penulis konsekuensinya adalah klausula tentang pembubaran ormas tidak ada norma hukumnya bergeser menjadi “pencabutan status badan hukum'. Implikasinya ketika sudah ada pencabutan dianggap secara otomatis bubar. Keterlibatan Pengadilan sebagai celah awal pembubaran tidak ada. Perubahan norma hukum tersebut jelas telah mengesampingkan asas rechstaats.

$$
\text { Perdebatan yang kemudian }
$$
muncul adalah terkait pembubaran Ormas dalam UU Ormas 2013 dan Undang-Undang Nomor 16 Tahun 2017 tentang Penetapan Perppu Nomor 2 Tahun 2017 tentang Perubahan Atas UU No. 17 Tahun 2013 tentang Organisasi Kemasyarakatan. Hal ini karena dalam UU Keormasan pemerintah seakan dapat menggunakan kewenangannya untuk membubarkan ormas yang dirasa bertentangan dengan pemerintah tanpa adanya putusan pengadilan terlebih dahulu. Padahal apabila kita menilik fungsi dari proses peringatan tertulis hingga pemeriksaan pengadilan dalam UU Ormas 2013 terdapat sebuah makna asas praduga tak bersalah terhadap ormas yang dinilai bertentangan dengan UU. Ormas masih diberi hak untuk membela diri dengan memberikan keterangan dan bukti di persidangan. Proses peradilan inilah yang kemudian dihilangkan dan dinilai mencederai nilai demokrasi.

Menurut penulis hadirnya Undang-Undang Nomor 16 Tahun 2017 tentang Penetapan Perppu Nomor 2 Tahun 2017 tentang Perubahan Atas Undang-Undang Nomor 17 Tahun 2013 tentang Organisasi Kemasyarakatan dalam konteks Indonesia sebagai negara hukum yang demokratis tidak perlu disikapi sebagai upaya pemerintah untuk membungkam kebablasan masyarakat untuk berserikat dan berkumpul dalam negara demokrasi di Indonesia. Mengingat negara masih memberikan jaminan, masyarakat dapat membentuk ormas dengan tujuan dan paham yang tidak bertentangan dengan Pancasila sebagai dasar Negara Indonesia.

Pembatasan ruang gerak organisasi kemasyarakatan ini penting, mengingat bangsa Indonesia sepakat Pancasila sebagai ideologi bangsa yang berdasarkan UUD NRI 1945 dalam bingkai Negara Kesatuan Republik Indonesia, jangan sampai cita-cita pendiri bangsa hancur karena ancaman dari ormas yang bertentangan dengan cita-cita pendiri Bangsa Indonesia. Pembatasan bukan dimaksudkan untuk mengekang kebebasan berserikat warga negara melainkan untuk menjaga agar Pancasila sebagai ideologi negara tidak terancam dengan adanya faham atau ideologi lain yang bertujuan untuk menggantikan ideologi Pancasila. 
2. Dimensi Kegentingan Yang Memaksa dalam Penerbitan Perppu Nomor 2 Tahun 2017 tentang Perubahan Atas UndangUndang Nomor 17 Tahun 2013 tentang Organisasi

\section{Kemasyarakatan}

Mengacu pada putusan MK No.138/PUU-VII/2009 maka syarat objektif "kegentingan memaksa" telah terpenuhi dalam Perppu Nomor 2 Tahun 2017 tersebut, yaitu:

Pertama, adanya keadaan yaitu kebutuhan mendesak untuk menyelesaikan masalah hukum secara cepat berdasarkan undang-undang, karena apabila ajaran atau paham yang bertentangan dengan Pancasila tersebut tidak dicegah sejak dini dikhawatirkan ajaran tersebut semakin menyebar dan diikuti oleh banyak orang sehingga akan mengancam Ideologi bangsa dan kedaulatan NKRI.

Kedua, ada Undang-Undang tetapi tidak memadai, seperti yang kita ketahui bersama bahwa pengaturan mengenai Ormas memang sudah diatur dalam Undang-Undang Nomor 17 Tahun 2013 tentang Organisasi kemasyarakatan, namun ketentuan tersebut sudah tidak lagi memadai dan tidak dapat menjawab kebutuhan hukum yang ada karena penjelasan mengenai Ormas yang menyebarkan paham/ideologi terbatas hanya pada atheisme, komunisme, marxisme/leninisme saja, padahal dalam perkembangannya masih banyak paham lain yang bertentangan dengan Pancasila selain paham-paham tersebut di atas, kemudian tidak tersedianya asas contrarius actus dalam Undang-Undang Nomor 17 Tahun 2013 menjadikan Pemerintah tidak dapat bertindak cepat dan tegas untuk menertibkan Ormas yang menyebarkan ideologi yang bertentangan dengan Pancasila.

Ketiga, kekosongan hukum tersebut tidak dapat diatasi dengan cara membuat undang-undang secara prosedur biasa karena membutuhkan waktu yang lama sedangkan keadaan mendesak tersebut perlu segera diselesaikan sehingga apabila menunggu revisi terhadap UndangUndang Nomor 17 Tahun 2013 tentunya akan membutuhkan waktu yang lama padahal kehadiran Ormas yang menyebarkan ideologi selain Pancasila tersebut mendesak untuk segera ditindak tegas.

\section{Kesimpulan}

a. Diterbitkannya Undang-Undang Nomor 16 Tahun 2017 tentang Penetapan Perppu Nomor 2 Tahun 2017 tentang Perubahan Atas Undang-Undang Nomor 17 Tahun 2013 tentang Organisasi Kemasyarakatan dalam konteks Indonesia sebagai negara hukum yang demokratis tidak perlu disikapi sebagai upaya pemerintah untuk membungkam keblabasan masyarakat untuk berserikat dan berkumpul dalam negara demokrasi di Indonesia. Mengingat negara masih memberikan jaminan, masyarakat dapat membentuk organisasi kemasyarakatan dengan tujuan dan paham yang tidak bertentangan dengan Pancasila sebagai dasar Negara Indonesia.

b. Mengacu pada putusan MK No.138/PUU-VII/2009 maka Syarat objektif "kegentingan memaksa" telah terpenuhi dalam Perppu Nomor 2 Tahun 2017 tersebut. Yaitu; Pertama, adanya keadaan yaitu kebutuhan mendesak untuk menyelesaikan masalah 
hukum secara cepat berdasarkan undang-undang, karena apabila ajaran atau paham yang bertentangan dengan Pancasila tersebut tidak dicegah sejak dini dikhawatirkan ajaran tersebut semakin menyebar dan diikuti oleh banyak orang sehingga akan mengancam Ideologi bangsa dan kedaulatan NKRI. Kedua, ada Undang-Undang tetapi tidak memadai, seperti yang kita ketahui bersama bahwa Pengaturan mengenai Ormas memang sudah di atur dalam Undang-Undang Nomor 17 Tahun 2013 tentang Organisasi kemasyarakatan, namun ketentuan tersebut sudah tidak lagi memadai dan tidak dapat menjawab kebutuhan hukum yang ada karena penjelasan mengenai Ormas yang menyebarkan paham/ ideologi terbatas hanya pada atheisme, komunisme, marxisme/ leninisme, padahal dalam perkembangannya masih banyak paham lain yang bertentangan dengan Pancasila selain paham-paham tersebut di atas, kemudian tidak tersedianya asas contrarius actus dalam Undang-Undang Nomor 17 Tahun 2013 menjadikan Pemerintah tidak dapat bertindak cepat dan tegas untuk menertibkan Ormas yang menyebarkan ideologi yang bertentangan dengan Pancasila. Ketiga, kekosongan hukum tersebut tidak dapat diatasi dengan cara membuat Undang-Undang secara prosedur biasa karena membutuhkan waktu yang lama sedangkan keadaan mendesak tersebut perlu segera diselesaikan sehingga apabila menunggu revisi terhadap Undang-Undang Nonor 17 Tahun 2013 tentunya akan membutuhkan waktu yang lama padahal kehadiran Ormas yang menyebarkan ideologi selain Pancasila tersebut mendesak untuk segera di tindak tegas.

\section{DAFTAR PUSTAKA}

Maria Farida Indrati S., 2007, "Ilmu Perundang-Undangan: Jenis Fungsi dan Materi Muatan”, Kanisius, Yogyakarta.

Sudjito, 19 Oktober 2017, "Membaca 'Kepentingan Politik' Di Balik Perppu

Ormas dan Implikasi

Sosiologisnya Terhadap

Masyarakat”, Seminar Nasional

Quo Vadis Perppu Ormas

Universitas Islam Indonesia (UII),

Yogyakarta.

Jimly Asshiddiqie, 2006, "Perkembangan dan Konsolidasi Lembaga Negara

Pasca reformasi”, Sekretariat Jenderal dan Kepaniteraan Mahkamah Konstitusi RI, Jakarta.

Fuady Munir, 2009, “Konsep Negara Demokrasi”, Retika Aditama, Jakarta Maria Farida Indrati Soeprapto, 1998, "Ilmu Perundang-undangan Dasar-Dasar dan Perkembangannya", Kanisius, Yogyakarta. 